\title{
Chapter 17 \\ Water Erosion and Sediment Transport in an Ungauged Semiarid Area: The Case of Hodna Basin in Algeria
}

\author{
Omar Djoukbala, Mahmoud Hasbaia, Oussama Benselama, \\ Boutaghane Hamouda, Salim Djerbouai, and Ahmed Ferhati
}

\begin{abstract}
This study aims to estimate the eroded and transported sediment yields from the The Hodna basin $\left(26,000 \mathrm{~km}^{2}\right)$ situated in central Algeria by two approaches. In the first model, the data of the gauged subbasins are extrapolated to the ungauged areas based on the homogeneity of factors that influence the water erosion-sediment transport process. In this approach, the specific eroded and transported sediment yield in the Hodna basin is estimated to be $425 \mathrm{t} / \mathrm{km}^{2} / \mathrm{yr}$. In an alternative approach, the eroded yield is estimated by mapping erosion using the (RUSLE) in a GIS environment. The obtained results show a high eroded sediment yield of approximately $610 \mathrm{t} / \mathrm{km}^{2} / \mathrm{yr}$.

The observed difference between the results of the two approaches can be explained by the amount of sediment that is eroded but is not transported by runoff.

These two methods show high eroded and transported sediment yield values in the Hodna basin region; these high yields may seriously threaten the central flat zone with progressive deposition.
\end{abstract}

Keywords Ungauged watershed - Regionalization - Soil erosion - RUSLE • Hodna • Algeria

This study aims to estimate the eroded and transported sediment yields from the Hodna basin $\left(26,000 \mathrm{~km}^{2}\right)$ situated in central Algeria by two approaches. In the first model, the data of the gauged subbasins are extrapolated to the ungauged areas based on the homogeneity of factors that influence the water erosion-sediment transport process. In this approach, the specific eroded and transported sediment yield in the

\footnotetext{
O. Djoukbala $(\bowtie)$

Department of Hydraulics, University of Sidi Bel Abbès, BP 89, 22000 Sidi Bel Abbes, Algeria

O. Djoukbala · M. Hasbaia · O. Benselama · S. Djerbouai · A. Ferhati CEHSD Laboratory, University of M'sila, 166 Ichebilia, 28000 M'sila, Algeria

B. Hamouda

Badji-Moukhtar University of Annaba, Annaba, Algeria

(C) The Author(s) 2022

T. Sumi et al. (eds.), Wadi Flash Floods, Natural Disaster Science and Mitigation

Engineering: DPRI Reports, https://doi.org/10.1007/978-981-16-2904-4_17
} 
Hodna basin is estimated to be $425 \mathrm{t} / \mathrm{km}^{2} / \mathrm{yr}$. In an alternative approach, the eroded yield is estimated by mapping erosion using the (RUSLE) in a GIS environment. The obtained results show a high eroded sediment yield of approximately $610 \mathrm{t} / \mathrm{km}^{2} / \mathrm{yr}$.

The observed difference between the results of the two approaches can be explained by the amount of sediment that is eroded but is not transported by runoff.

These two methods show high eroded and transported sediment yield values in the Hodna basin region; these high yields may seriously threaten the central flat zone with progressive deposition.

\subsection{Introduction}

Soil loss due to water erosion is a real risk to the prosperity of humans and ecosystems. Soil erosion is responsible for approximately $85 \%$ of the degradation of our planet (Angima et al. 2003), and it is a complex phenomenon that affects large areas of the world. In fact, water erosion is very severe, especially in the southern Mediterranean, affecting nearly 7 million hectares of agricultural soils in Algeria.

Algeria is one of the regions that are most prone to flooding (Boudani et al. 2020) and water erosion, with a specific soil loss up to $4000 \mathrm{t} / \mathrm{km}^{2} /$ year (Demmak 1982) causing a large loss of fertile soil, which leads to low crop yields and associated environmental degradation. Water erosion is affected by many factors, the most important of which are climatic conditions (rain intensity), soil characteristics, topography, and human activities (Dinka 2020). The transport of eroded sediment depends on the drainage capacity, vegetal cover, and channel slope of the affected watershed.

In Algeria, the first measurements of sediment transport began in 1946 at the Traille gauging station, which controls the upper basin of the Isser wadi (Medinger 1960; Demmak 1982). With the installation of other stations, several studies have been conducted to explore the phenomena of erosion and sediment transport (Hasbaia et al. 2017); these studies have shown high rates of soil erosion and sediment transport in all regions of the country (Table 17.1).

In Algeria, gauging stations ensure that flow discharges $\left(\mathrm{m}^{3} / \mathrm{s}\right)$ and suspended sediment concentrations $(\mathrm{g} / \mathrm{l})$ are measured. The number of samples taken at gauging stations is adapted to the hydrological regime; during low flows with little difference, only one sample is taken every $24 \mathrm{~h}$. However, during the flood period, the sampling rate increases until the sampling frequency reaches every 10,15 , or 30 min during the peak of the flood. The flow discharges are determined directly from the rating curves by the water elevation, which is measured by means of a ladder or float. For each elevation measurement, water samples are taken near the riverbank to estimate the concentrations of suspended sediment. The water samples are filtered through 145-LM filter paper. The collected mass of sediment is weighed after drying at $105{ }^{\circ} \mathrm{C}$ for $24 \mathrm{~h}$. The estimated suspended sediment concentration is considered to be the average over the cross section of the river, and the sediment discharge is calculated as the product of this concentration and the flow discharge. 
Table 17.1 Specific erosion in Algerian catchments

\begin{tabular}{l|l|l|l|l|l}
\hline Authors & Watershed & Period & $\begin{array}{l}\mathrm{A} \\
\left(\mathrm{km}^{2}\right)\end{array}$ & $\begin{array}{l}\mathrm{P} \\
(\mathrm{mm})\end{array}$ & $\begin{array}{l}\text { Ass (t/ } \\
\left.\mathrm{km}^{2} / \mathrm{yr}\right)\end{array}$ \\
\hline Hasbaia et al. (2012) & Wadi El Ham & $1968-1989$ & 5605 & 185 & 530 \\
\hline $\begin{array}{l}\text { Bouchelkia et al. } \\
(2014)\end{array}$ & Wadi Chellif & $1972-2000$ & 43,700 & - & 94.27 \\
\hline Bouguerra et al. (2016) & $\begin{array}{l}\text { Wadi } \\
\text { Boumessoud }\end{array}$ & $1988-2004$ & 118 & 396 & 518 \\
\hline $\begin{array}{l}\text { Selmi and Khanchoul } \\
(2016)\end{array}$ & $\begin{array}{l}\text { Wadi } \\
\text { Mellegue }\end{array}$ & $1970-2003$ & 4575 & 270 & 589.23 \\
\hline $\begin{array}{l}\text { Madani Cherif et al. } \\
\text { (2017) }\end{array}$ & $\begin{array}{l}\text { Wadi El } \\
\text { Hammam }\end{array}$ & $1986-2008$ & 7440 & 400 & 111 \\
\hline Achit et al. (2017) & Wadi Sebaou & $1968-1999$ & 2500 & - & 147.32 \\
\hline Hasbaia et al. (2017) & Wadi Soubella & $1974-1989$ & 183.5 & 288.5 & 126 \\
\hline Balla et al. (2017) & Wadi Reboa & $1985-2012$ & 327 & 458 & 678 \\
\hline Balla et al. (2017) & Wadi Soultez & $1985-2012$ & 207 & 330 & 575 \\
\hline Belarbi et al. (2018) & Wadi Tafna & $1997-2011$ & 6900 & - & 196.11 \\
\hline Benselama et al. (2019) & $\begin{array}{l}\text { Wadi El } \\
\text { Maleh }\end{array}$ & $1981-1998$ & 932.5 & 383 & 294 \\
\hline A: & & & &
\end{tabular}

A: area, P: precipitation, Ass: specific soil erosion

In most cases, only suspended loads are measured, and bed load transfer measurements are lacking as they are difficult to measure. However, the suspended fraction is predominant ( $\mathrm{Lu}$ et al. 2012) and generally accounts for approximately $90 \%$ of the total flowing sediments (Walling and Fang 2003).

In gauged areas, instantaneous measures of suspended sediment concentrations and water discharges are used in several approaches to assess and model erosion and sediment transport dynamics. The sediment rating curve (SRC) is one of the most commonly used and validated models for sediment transport studies of Algerian watersheds (Hasbaia et al. 2017; Benselama et al. 2018). The SRC can be applied to evaluate the sediment yield with a known flow and sediment concentration (Zhang et al. 2015). Other approaches are also used for the same purpose, including conceptual, distributed, and semidistributed hydrologic models.

While hydrological data are available for some gauged watersheds, predicting hydrological variables in ungauged watersheds is still a major challenge (Gibson and Hancock 2019). According to Choubin et al. (2019), reliable estimations of stream flow and sediment transport, particularly in ungauged watersheds, are the most important factors for environmental management and planning.

The availability of satellite data, which are currently easily accessible, can help in mapping erosive hazards. Moreover, approaches and models using GIS and remote sensing are increasingly used in Algeria to derive variables that are necessary for estimating soil erosion (Benchettouh et al. 2017; Benselama et al. 2018; Toubal et al. 2018).

The Hodna basin is the fifth-largest watershed in Algeria, with a drainage area of approximately $26,000 \mathrm{~km}^{2}$. The basin is characterized by a semiarid climate with 


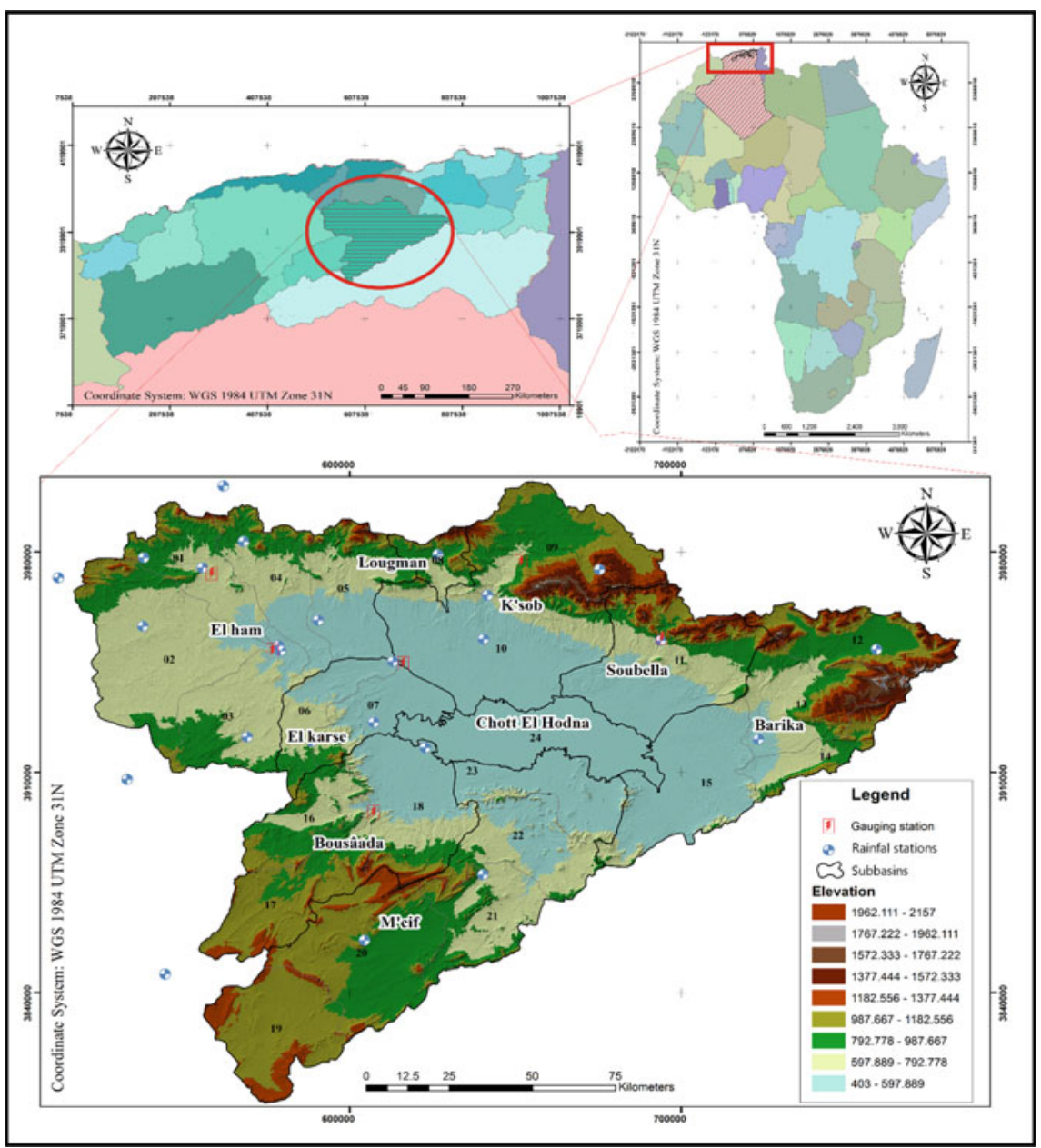

Fig. 17.1 Hodna basin

high temperatures and low rainfall associated with high spatiotemporal variability. The Hodna basin records an average annual rainfall of $363 \mathrm{~mm} / \mathrm{year}$, and the maximum daily rainfall is approximately $36.6 \mathrm{~mm}$. The Hodna basin is located in the center of Algeria (Fig. 17.1) between two sets of mountains in the north and the south; it is an endorheic watershed around an almost flat depression at an altitude of $392 \mathrm{~m}$. At the center of this depression, a dry salt lake named "Chott El Hodna" $\left(1150 \mathrm{~km}^{2}\right)$ receives all water and solid yields from the 13 main subbasins of the watershed, which poses serious problems involving flooding and the deposition of sediment.

The main purpose of this study is to assess the soil degradation and sediment yield in the Hodna basin where $72 \%$ of the basin area is ungauged. Two 
frameworks are employed. One is based on the regionalization concept and includes extrapolating data from the gauged areas to the ungauged subbasins. The second approach is based on RUSLE mapping and uses remote sensing in a GIS environment.

\subsection{Methods and Materials}

\section{Study area:}

The Hodna basin is the fifth-largest watershed in Algeria, with a drainage area of approximately $26,000 \mathrm{~km}^{2}$ (Fig. 17.1). It is an interior endorheic watershed situated $150 \mathrm{~km}$ south of the Mediterranean coast. It is also organized as a closed, flat area (at an altitude of $392 \mathrm{~m}$ ) between two sets of mountains to the north and south. This area receives sediment yields and water from all the subbasins of the region, and the center of this basin consists of the Chott El Hodna, a saline lake $\left(1150 \mathrm{~km}^{2}\right)$.

According to the National Agency of Hydraulic Resources, the Hodna basin can be divided into 23 subbasins, and the 24th, central subbasin is the lake Chott El Hodna (Table 17.2); however, these subbasins can be grouped into eight hydrographic subbasins, each with the same principal thalweg or the same outlet. The semiarid climate of the Hodna basin is characterized by high temperatures and low rainfall associated with high spatiotemporal variability. The months of June, July, and August are the warmest, with temperatures of approximately $40{ }^{\circ} \mathrm{C}$, while the months of December, January, and February record drops in temperature reaching $-3{ }^{\circ} \mathrm{C}$. The study area is characterized by high spatiotemporal variability in rainfall, which varies from 130 to $450 \mathrm{~mm}$.

To measure the instantaneous water discharge and suspended sediment concentrations, the Hodna basin is equipped with seven gauging stations; these stations were installed between 1966 and 1970, but not all of the stations are in service. An examination of the available data shows that only data from three stations are reliable: the Medjez station in the wadi K'sob subbasin, the Sidi Ouadah station in the wadi Soubella subbasin, and the Rocade-sud station at the outlet of the wadi El ham subbasin. The Hodna basin is partially gauged, and only $28 \%$ of the total surface area is measured; the rest of the watershed (72\%) is ungauged.

\section{Methods}

In this paper, the sediment yield and specific erosion of the Hodna basin are estimated by two approaches.

The first approach is developed from a regionalization concept based on the similarity of the parameters that influence runoff, sediment transport, and soil loss, especially rainfall behavior and terrain slope. The Hodna subbasins can be organized into two groups: the northern subbasin group and the southern subbasin group. The first subbasin group (northern) is characterized by relatively high rainfall, dense vegetative cover, and a steep land slope. The second subbbasin group 
Table 17.2 Hodna subbasins

\begin{tabular}{|c|c|c|c|}
\hline \multicolumn{2}{|c|}{ Subbasins of the Hodna basin } & \multicolumn{2}{|c|}{$\begin{array}{l}\text { Hydrographic subbasin } \\
\text { of the Hodna basin }\end{array}$} \\
\hline Name & $\begin{array}{l}\text { Area } \\
\left(\mathrm{km}^{2}\right)\end{array}$ & Name & $\begin{array}{l}\text { Area } \\
\left(\mathrm{km}^{2}\right)\end{array}$ \\
\hline $1 \mathrm{El} \mathrm{ham}$ & 805.80 & \multirow[t]{6}{*}{ El ham } & \multirow[t]{6}{*}{6817.61} \\
\hline 2 Sbissebe & 1851.98 & & \\
\hline 3 Guernini & 1071.31 & & \\
\hline 4 Djenene & 860.47 & & \\
\hline 5 Torga & 1026.94 & & \\
\hline $6 \mathrm{El}$ karsa & 553.12 & & \\
\hline 7 El leham & 647.99 & El leham & 647.99 \\
\hline 8 Lougman & 333.75 & Lougman & 333.75 \\
\hline $9 \mathrm{~K}$ 'sob & 1471.20 & \multirow[t]{2}{*}{ K'sob } & \multirow[t]{2}{*}{3628.72} \\
\hline 10 M'sila & 2157.52 & & \\
\hline 11 Soubella & 1768.97 & Soubella & 1768.97 \\
\hline 12 Barika amont & 889.77 & \multirow[t]{4}{*}{ Barika } & \multirow[t]{4}{*}{3804.24} \\
\hline 13 Barika aval & 1007.05 & & \\
\hline 14 Barriche & 504.40 & & \\
\hline 15 Bithem Barika & 1403.02 & & \\
\hline 16 Maiter amont & 672.74 & \multirow[t]{3}{*}{ Boussaâda } & \multirow[t]{3}{*}{2940.75} \\
\hline 17 Boussaâda & 1035.15 & & \\
\hline 18 Maiter aval & 1232.86 & & \\
\hline 19 Ain Rich & 1130.88 & \multirow[t]{5}{*}{ M'cif } & \multirow[t]{5}{*}{5323.27} \\
\hline 20 Chair amont & 1597.78 & & \\
\hline 21 Chair aval & 877.75 & & \\
\hline 22 M'cif amont & 924.20 & & \\
\hline 23 M'cif aval & 792.66 & & \\
\hline $\begin{array}{l}24 \text { Chott El } \\
\text { Hodna }\end{array}$ & 1216.81 & 1 & 1 \\
\hline
\end{tabular}

(southern) is characterized, contrary to the first group, by low rainfall and gradual land slopes with poor vegetative cover.

The homogeneity of the two main parameters (terrain slope and rainfall) in each group is well-justified, and the vegetative cover has the same trend in the subbasins of each group. An analysis of the terrain slope generated from a digital terrain model of all the subbasins of the Hodna basin confirms that the slopes of all the southern subbasins are less than $10 \%$, contrary to the northern subbasins (Table 17.3). Concerning rainfall, we focused on the spatial distribution of annual rainfall while assuming that the other rainfall parameters (rain intensity, maximum daily rainfall, etc.) have the same distribution.

To identify the two groups, we used an annual rainfall map of the Hodna basin. Then, we measured, for each subbasin, the area fraction with rainfall amounts ranging from 150 to $200 \mathrm{~mm}$ and from 300 to $400 \mathrm{~mm}$ (Fig. 17.2). Analyzing this 
Table 17.3 Terrain slope of the Hodna subbasins

\begin{tabular}{l|l|l}
\hline Subbasin & Terrain slope (\%) & Group \\
\hline Lougman & 12.14 & I \\
K'sob & 11.08 & slope $>10 \%$ \\
\hline Soubella & 10.78 & \\
\hline Barika & 10.23 & II \\
\hline El ham & 6.53 & Slope $<10 \%$ \\
El Leham & 5.98 & \\
\hline Bousâada-Maitar & 8.87 & \\
\hline M'cif & 7.68 &
\end{tabular}

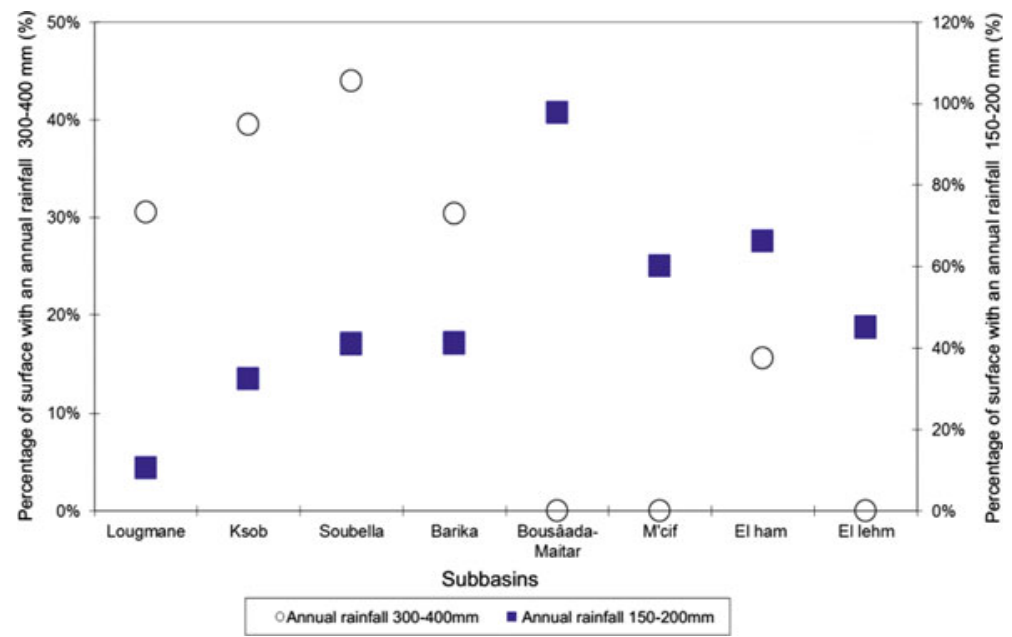

Fig. 17.2 Annual rainfall distributions in Hodna subbasins

latter figure, we clearly observed that most of the northern subbasin areas have annual rainfall between 300 and $400 \mathrm{~mm}$, unlike the southern subbasins, in which the rainfall amount ranges from 150 to $200 \mathrm{~mm}$.

In the northern subbasin group, comprising the four subbasins of K'sob $(3628.72$ $\mathrm{km}^{2}$ ), Lougman $\left(333.75 \mathrm{~km}^{2}\right)$, Soubella $\left(1768.97 \mathrm{~km}^{2}\right)$, and Barika $\left(3804.24 \mathrm{~km}^{2}\right)$, there are only two gauging stations, the K'sob and Sidi Oudah stations, which are installed in the K'sob and Soubella subbasins, respectively. The two other subbasins (Lougman and Barika) are ungauged. The whole area of this subbasin group has a land slope greater than $10 \%$, with average annual rainfall between 300 and $400 \mathrm{~mm}$ and relatively dense vegetal cover.

Among the four subbasins of the second group, El ham $\left(6817.61 \mathrm{~km}^{2}\right)$, Bousaâda (2940.75 km²), M'cif $\left(5323.27 \mathrm{~km}^{2}\right)$, and El leham $\left(647.99 \mathrm{~km}^{2}\right)$, only the El ham subbasin is gauged; it is equipped by the Rocade-sud gauging station situated at its outlet. This subbasin group is characterized by moderate land slopes 
and low annual rainfall, with values $<10 \%$ and between 100 and $200 \mathrm{~mm}$, respectively. The vegetal cover in this group is also poor (Hasbaia et al. 2012).

This regionalization of the Hodna basin allows the extrapolation of the calculated specific soil losses (A) from the gauged subbasins to the ungauged subbasins in the same group. In the northern subbasin group, the sediment yields of the ungauged subbasins (wadi Lougman and wadi Barika) are calculated using the specific erosions of the gauged subbasins, wadi K'sob, and wadi Soubella, respectively. In the southern subbasin group, there is only one gauged basin, wadi El- ham; therefore, the sediment yields of the ungauged subbasins (wadi Bousâada, wadi M'cif, and wadi El leham) are calculated from its specific erosion.

The second approach consists of mapping soil loss due to water erosion in the Hodna watershed using the Revised Universal Soil Loss Equation (RUSLE) (Wischmeier and Smith 1978) in a GIS environment. This equation estimates soil erosion (A) by multiplying the five RUSLE factor maps, defined as the specific soil erosion (A) $\left(\mathrm{t} / \mathrm{km}^{2} / \mathrm{yr}\right)$, the rainfall erosivity $(\mathrm{R})(\mathrm{MJ} \mathrm{mm} / \mathrm{ha} / \mathrm{h} / \mathrm{yr})$, the soil erodibility $(\mathrm{K})(\mathrm{Mg} \mathrm{h} / \mathrm{MJ} / \mathrm{mm})$, the topography factor (LS), crop management $(\mathrm{C})$, and erosion control practices (P) (Table 17.4).

$$
A=R \times K \times L S \times C \times P
$$

In this approach, we used the data of 25 rainfall stations situated inside and around the Hodna basin. The rainfall erosivity (Fig. 17.3) was calculated at all stations and spatialized over the whole watershed surface by inverse distance weighting (IDW) interpolation in a GIS environment. To characterize the soil erodibility (K) map (Fig. 17.4), we used the harmonized world soil database (HWSD) (Djoukbala et al. 2019). The map of topographic factors (LS) was obtained from a digital elevation model (DEM) with an accuracy of $30 \mathrm{~m}$ in a GIS

Table 17.4 Description of the data used

\begin{tabular}{l|l|l|l|l}
\hline Parameter & Materials & $\begin{array}{l}\text { Resolution } \\
(\mathrm{m})\end{array}$ & Year & Source \\
\hline NDVI data & $\begin{array}{l}\text { Landsat } \\
\text { satellite }\end{array}$ & 30 & 2019 & http://earthexplorer.usgs.gov/ \\
\hline Rainfall data & $\begin{array}{l}\text { Monthly/ } \\
\text { annual } \\
\text { rainfall } \\
\text { data }\end{array}$ & 30 & $\begin{array}{l}1985- \\
2015\end{array}$ & $\begin{array}{l}\text { National Agency for Hydraulic } \\
\text { Resources (NAHR) }\end{array}$ \\
\hline $\begin{array}{l}\text { Soil } \\
\text { properties }\end{array}$ & (HWSD) & 90 & - & $\begin{array}{l}\text { The Harmonized World Soil } \\
\text { Database } \\
\text { http://webarchive.iiasa.ac.at/ } \\
\text { Research/LUC/External-World- } \\
\text { soil-database/HTML/ }\end{array}$ \\
\hline $\begin{array}{l}\text { Topographic } \\
\text { data }\end{array}$ & $\begin{array}{l}\text { Aster } \\
\text { global } \\
\text { DEM }\end{array}$ & 30 & 2019 & http://earthexplorer.usgs.gov/ \\
\hline
\end{tabular}




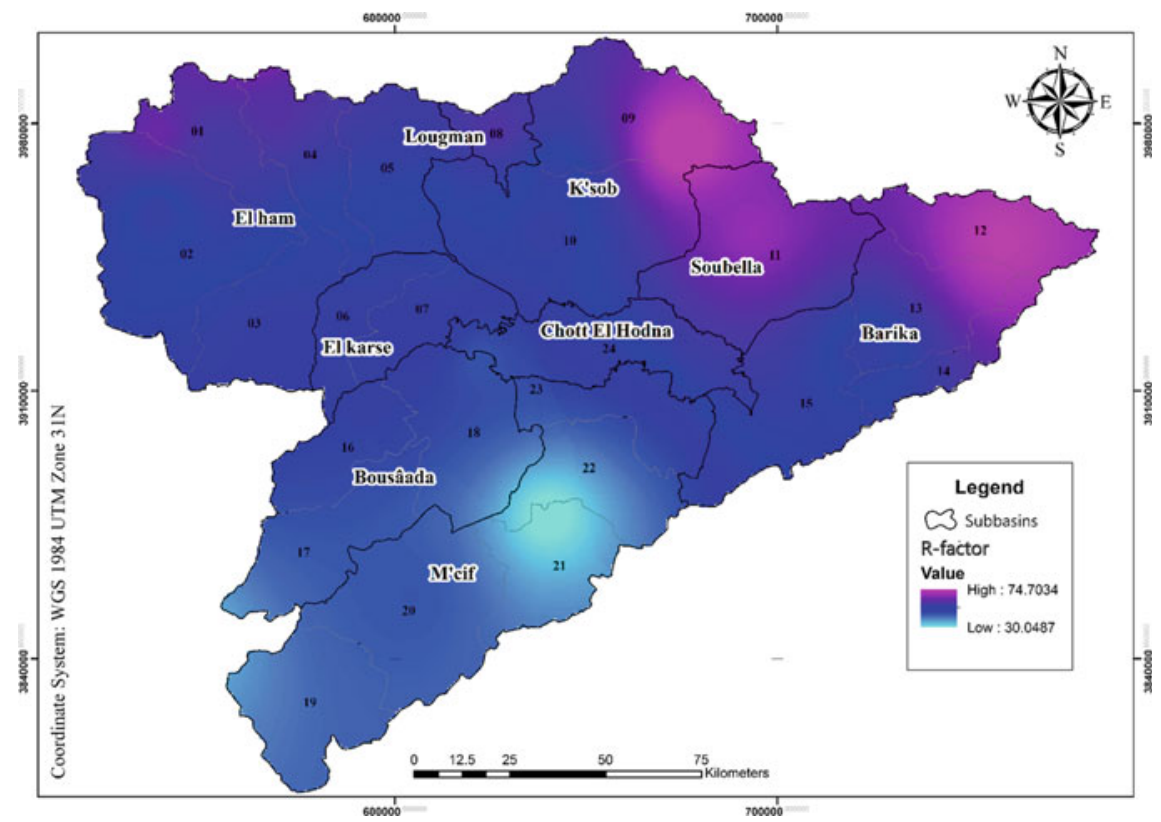

Fig. 17.3 Map of rainfall erosivity

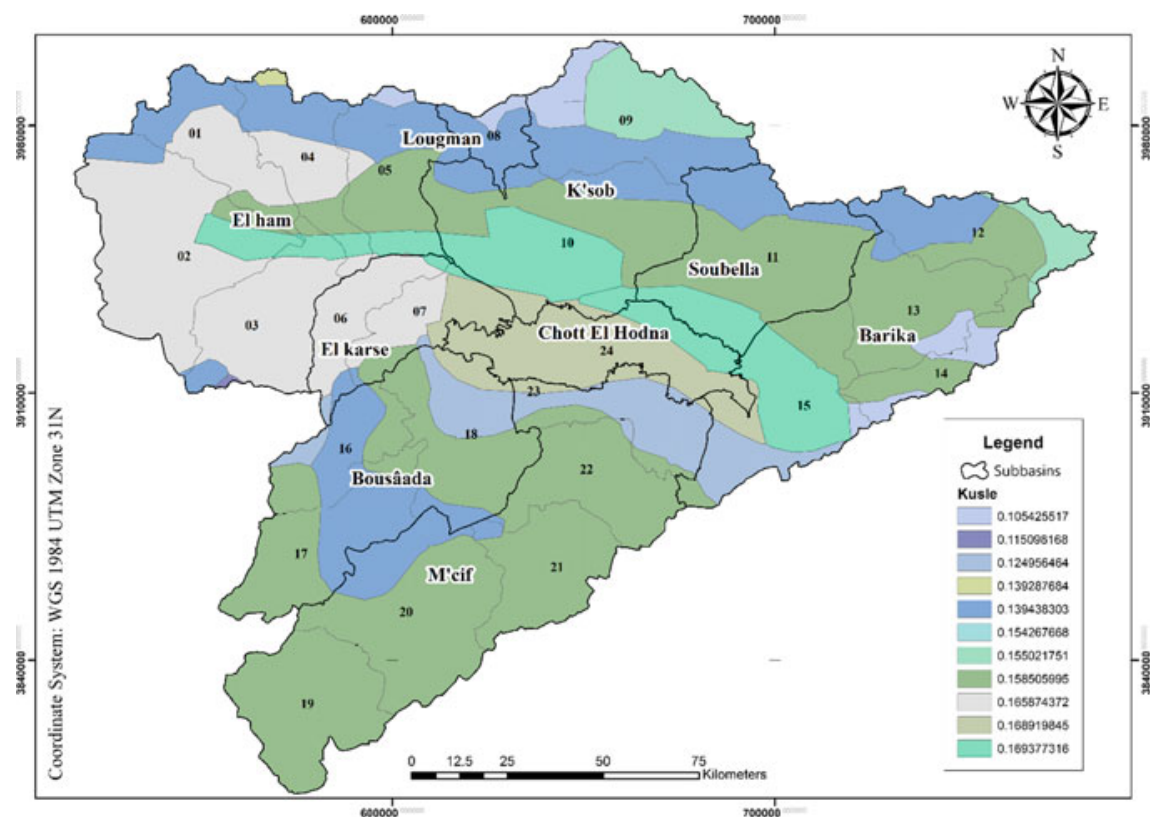

Fig. 17.4 Map of soil erodibility 


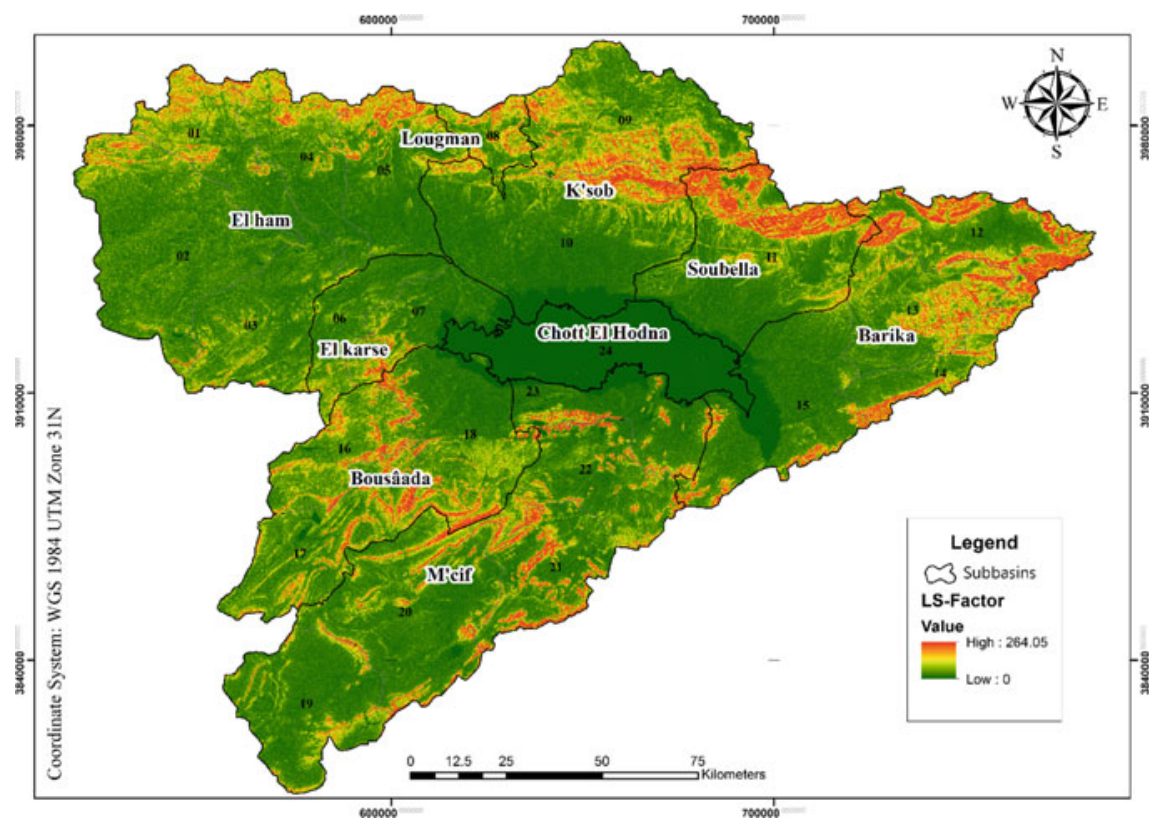

Fig. 17.5 Map of the topographic factor (LS)

environment (Fig. 17.5). To map the crop management factor (C), we used normalized difference vegetation index (NDVI) data (period 2019) obtained by the Landsat 8 satellite. To estimate the values of factor $C$ in the study area (Fig. 17.6), we used the regression between two extreme values. These values are taken from experimental diagram (Gitas et al. 2009). The equation of the regression line found is as follows:

$$
C=0.9167-N D V I \times 1.1667
$$

The erosion control methods in the Hodna basin are very modest; therefore, the factor $\mathrm{P}$ is taken to be equal to one. The superposition of the five-factor maps for the Revised Universal Soil Loss Equation allowed the mapping of specific soil loss over the whole surface of the Hodna watershed (Fig. 17.7).

\subsection{Results and Discussion}

Based on the first approach, we calculated specific soil erosion from the measured data of three gauging stations: Medjez, Sidi Ouadah, and Rocade-sud (Table 17.5). The obtained values were extrapolated to the ungauged subbasins to estimate their sediment yields and corresponding specific soil erosion rates (Table 17.6). 


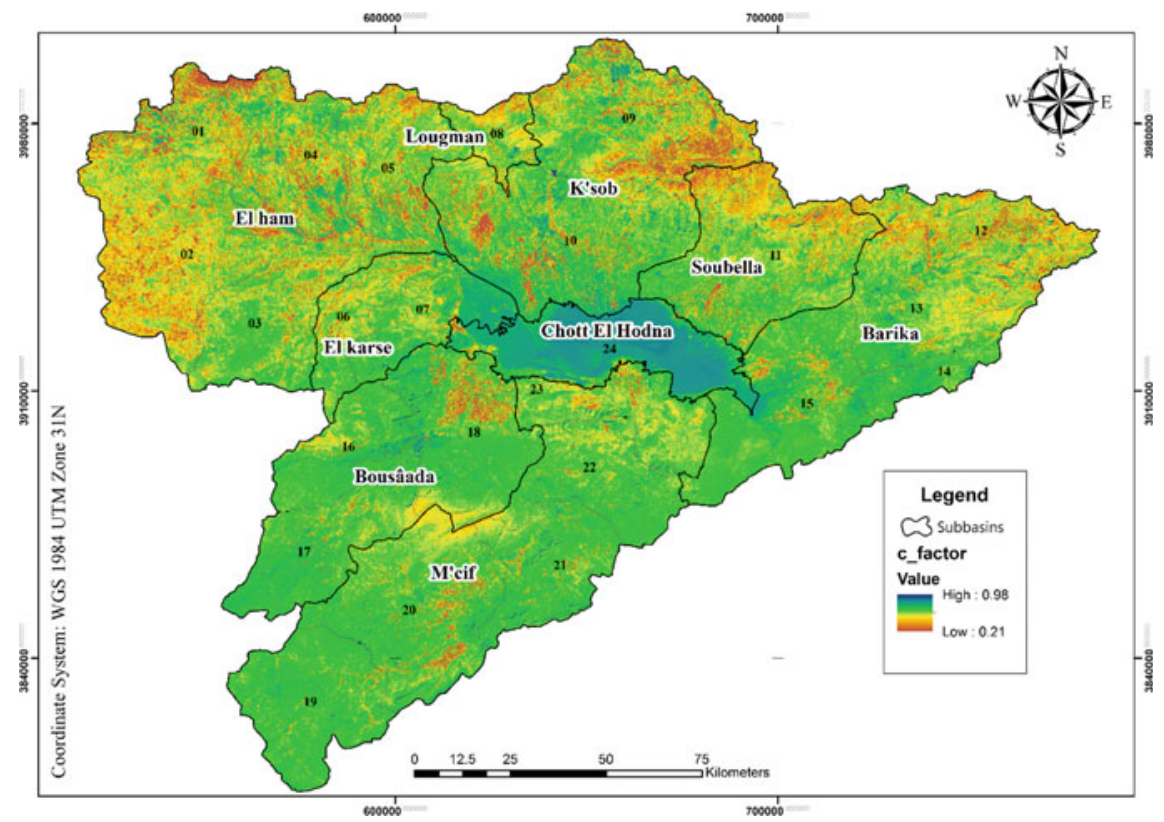

Fig. 17.6 Map of the C-factor

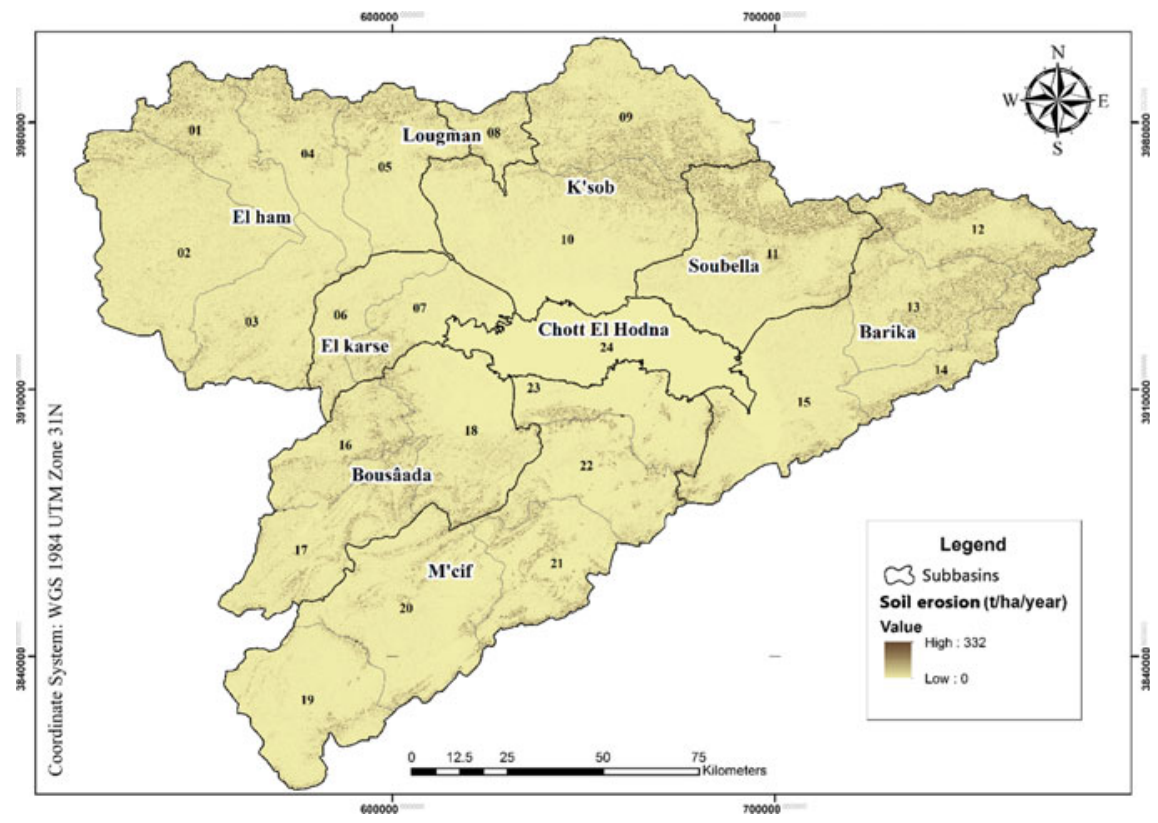

Fig. 17.7 Map of soil loss in Hodna basin 
Table 17.5 Specific erosion of gauged subbasins

\begin{tabular}{l|l|l|l}
\hline Subbasin & El Ham & K'sob & Soubella \\
\hline Specific erosion $\left(\mathrm{t} / \mathrm{km}^{2} / \mathrm{yr}\right)$ & 529.26 & 430.00 & 239.50 \\
\hline
\end{tabular}

Table 17.6 Specific erosion and sediment yields of the Hodna basin

\begin{tabular}{|c|c|c|c|c|c|}
\hline Approach & I & & & II & \\
\hline Subbasin & $\begin{array}{l}\text { Water yield } \\
\text { (million } \mathrm{m}^{3} / \\
\text { yr) }\end{array}$ & $\begin{array}{l}\text { Sediment yield } \\
\text { (million } \mathrm{t} / \mathrm{yr} \text { ) }\end{array}$ & $\begin{array}{l}\text { Specific } \\
\text { erosion (t/ } \\
\left.\mathrm{km}^{2} / \mathrm{yr}\right)\end{array}$ & $\begin{array}{l}\text { Specific } \\
\text { erosion }(\mathrm{t} / \\
\left.\mathrm{km}^{2} / \mathrm{yr}\right)\end{array}$ & $\begin{array}{l}\text { Error } \\
(\%)\end{array}$ \\
\hline El ham & 94.35 & 2.97 & 529.26 & 571.78 & 7.4 \\
\hline El leham & 9.69 & 0.63 & 529.26 & 601.80 & 12.1 \\
\hline Lougman & 9.61 & 0.14 & 430.00 & 528.49 & 18.6 \\
\hline K'sob & 102.88 & 1.56 & 430.00 & 595.67 & 27.8 \\
\hline Soubella & 19.76 & 0.42 & 239.50 & 490.00 & 51.1 \\
\hline Barika & 40.90 & 0.91 & 239.50 & 438.34 & 45.4 \\
\hline Busaâda & 44.84 & 1.55 & 529.26 & 549.86 & 3.7 \\
\hline M'cif & 80.59 & 2.81 & 529.26 & 585.67 & 9.6 \\
\hline
\end{tabular}

From this regionalization approach, the above numbers show the high dynamics of soil degradation and sediment transport in the Hodna region; approximately, 11 million tons of sediment and 403 million $\mathrm{m}^{3}$ of water are lost annually, with a specific erosion of $425 \mathrm{t} / \mathrm{km}^{2} / \mathrm{yr}$ (among the highest in Algeria) in the whole Hodna basin. Taking into account the temporal variability of the water and sediment yields estimated in the Hodna basin as $120 \%$ and $100 \%$, respectively, these yields can reach 860 million $\mathrm{m}^{3}$ of water and 22 million tons of sediment. The only dam in the Hodna basin, "K'sob," is almost entirely silted, and it mobilizes less than 10 million $\mathrm{m}^{3}$ of water; therefore, spectacular volumes of water and sediment are spilled into the Chott, causing serious problems involving inundation and sediment deposition. The sediment volume can increase the terrain level of the Chott El Hodna by approximately $2 \mathrm{~cm}$ every year, i.e., $20 \mathrm{~cm}$ in 10 years on the whole of the supposed flat surface $\left(1150 \mathrm{~km}^{2}\right)$. If we consider the variation of the topography, all the depressions in this region can be bridged in fewer than ten years, which explains why several roads and bridges were raised several times last year; the villages of the region are also threatened.

The water yield also presents a real danger; it could immerse the entirety of the saline lake Chott El Hodna with a water depth of $74 \mathrm{~cm}$ if the terrain is assumed to be flat, which means that any depression is threatened by flooding. Due to this high water yield, the risk of the spread of saline water is also increasing (Hasbaia et al. 2012).

The use of remote sensing (RS) techniques in a geographic information system (GIS) environment allows the quantitative estimation of erosion as well as its spatial distribution at a low cost and with a significant degree of accuracy for large areas, 
particularly since policy creators are much more interested in the distribution of erosion risk than in its absolute value ( $\mathrm{Lu}$ et al. 2004).

The quantitative estimation of soil erosion was carried out by applying empirical point models, which require input parameters including specialized data (slopes, soil texture, rainfall, etc.) characterizing water erosion factors (topography, erodibility, erosivity, etc.) (Le Bissonnais et al. 2004).

According to Wishmeier's equation (RUSLE), the average annual soil loss(A) was estimated from the different factors (rainfall erosivity $(\mathrm{R})$, soil erodibility $(\mathrm{K})$, topography (LS), cropping management (C), and support practice (P)) using spatial analysis with ArcGIS software, which represents a geoenvironmental scenario for the study area. A soil loss map (Fig. 17.7) of the entire watershed area was obtained by the superposition of the generated maps of each previous factor.

The results indicate that the annual rate of soil erosion ranged from 0 to $332 \mathrm{t} / \mathrm{ha} /$ $\mathrm{yr}$, with an average of $6.10 \mathrm{t} / \mathrm{ha} / \mathrm{yr}$; this value is very close to the results obtained in similar studies in the Hodna region (Djoukbala et al. 2018; Hasbaia et al. 2018).

This approach also demonstrates that the RUSLE model combined with a geographic information system (GIS) is a practical and relevant method for assessing the spatial variability of soil erosion for the efficient and effective management of sediments and water quality.

According to the comparison between the two approaches, the values converge with variable errors from 3 to $50 \%$ (Table 17.5). Among the eight subbasins, we note that satisfactory results are obtained for the Busaâda, M'cif, El ham, El leham, and Lougman subbasins, with errors of $3.7 \%, 9.6 \%, 7.4 \%, 12.1 \%$, and $18.6 \%$, respectively, compared with those acquired by the regionalization approach. Diverse results are obtained for the K'sob, Barika, and Soubella subbasins, with errors up to $51 \%$.

This approach shows a very useful tool for predicting sediment degradation in ungauged areas. The comparison of the obtained results in only the gauged areas with reliable measured suspended sediment data shows an error less than $21 \%$. This error is acceptable if we take into account the mass of eroded sediments that do not reach the gauging stations located in the main channels.

\subsection{Conclusion}

The Hodna basin is a very large basin with an area of $26,000 \mathrm{~km}^{2}$; it is an endoreic basin that is partially gauged, and only $28 \%$ of the basin surface is measured by gauging stations. Estimating sediment yields and erosion risks in this basin presents a very important challenge. To this end, this paper presented two approaches: one based on the regionalization concept and the second based on RUSLE mapping. The soil loss in the Hodna basin presents average values of approximately 425 or $610 \mathrm{t} / \mathrm{km}^{2} / \mathrm{yr}$ as calculated by the first and second approaches, respectively. The value obtained from the RUSLE method is approximately $30 \%$ greater than that obtained from the regionalization approach. This rate is explained by the mass of 
eroded sediments that do not reach the gauging stations in the main channels. In fact, these two approaches are very complementary for estimating both the eroded and transported sediment rates.

The present results are similarly compatible with the results of other studies relating to water erosion assessments carried out in other Algerian basins with similar climatic and environmental characteristics. The specific soil loss has been evaluated as 570, 679, and $1118 \mathrm{t} / \mathrm{km}^{2} / \mathrm{yr}$ in the wadi El Ham watershed (Djoukbala et al. 2018), K'sob catchment (Hasbaia et al. 2018), and wadi Boumahdane (Bouguerra et al. 2017), respectively.

\section{References}

Achit M, Ballah A, Kamel Toubal A (2017) Etude de 1' ecoulemen t liquide et solide dans le bassin versant de 1' oued se baou au droit de la station hydrometrique de baghlia, Algerie. http://dspace.univ-ouargla.dz/jspui/handle/123456789/13919

Angima SD et al (2003) Soil erosion prediction using RUSLE for central Kenyan highland conditions. Agric Ecosyst Environ 97(1-3):295-308

Balla F, Kabouche N, Khanchoul K, Bouguerra H (2017) Hydro-sedimentary flow modelling in some catchments constantine highlands, Case of Wadis Soultez and Reboa (Algeria). J Water Land Dev 34(1):21-32. http://content.sciendo.com/view/journals/jwld/34/1/article-p21.xml

Belarbi F, Bouchelkia H, Remini B, Benmansour A (2018) Quantification and study of monthly variation of suspended sediment loads in Tafna Basin-Algeria. J Water Land Dev 37(1):2938. http://content.sciendo.com/view/journals/jwld/37/1/article-p29.xml

Benchettouh A, Kouri L, Jebari S (2017) Spatial estimation of soil erosion risk using RUSLE/GIS techniques and practices conservation suggested for reducing soil erosion in Wadi Mina Watershed (Northwest, Algeria). Arab J Geosci 10(4)

Benselama O, Mohamed M, Mahmoud H, Omar D, Sakher M (2018) Prediction of water erosion sensitive areas in mediterranean watershed, a case study of Wadi El Maleh in North-West of Algeria. Environ Monit Assess 190(12):735. http://link.springer.com/. https://doi.org/10.1007/ s10661-018-7117-1

Benselama O, Mohamed M, Mahmoud H, Omar D, Sakher M (2019) Analysis of the suspended sediment yield at different time scales in mediterranean watershed, case of Wadi El Maleh (North-West of Algeria). J Mediterr Earth Sci 11:3-13

Bouchelkia H, Belarbi F, Remini B (2014) Quantification of suspended sediment load by double correlation in the watershed of Chellif (Algeria). J Water Land Dev 21(1):39-46

Boudani MR, Mohamed M, Omar D et al (2020) Development of a minimalist conceptual numerical model for flood forecasting and management under GIS environment. J Water Clim Change

Bouguerra SA, Bouanani A, Baba-Hamed K (2016) Transport Solide Dans Un Cours d'eau En Climat Semi-Aride: Cas Du Bassin Versant de l'Oued Boumessaoud (Nord-Ouest de l'Algérie). Revue des sciences de l'eau 29(3):179. http://id.erudit.org/iderudit/1038923ar

Bouguerra H, Bouanani A, Khanchoul K et al (2017) Mapping erosion prone areas in the Bouhamdane watershed (Algeria) using the revised universal soil loss equation through GIS. J Water L Dev 32:13-23. https://doi.org/10.1515/jwld-2017-0002

Cherif M, Hayet KK, Bouanani A, Terfous A (2017) Prediction of sediment yield at storm period in Northwest Algeria. Arab J Geosci 10(9):1-17

Choubin B et al (2019) Streamflow regionalization using a similarity approach in ungauged basins: application of the geo-environmental signatures in the Karkheh River Basin, Iran. CATENA 182(February 2018), 104128. https://doi.org/10.1016/j.catena.2019.104128 
Demmak A (1982) Contribution à l'étude de l'érosion et Des Transports Solides En Algérie Septentrionale [Contribution to the Study of Erosion and Sediment Transport in Northern Algeria].” PhD Thesis. Manuscript. Paris. Université de Pierre et Marie Curie

Dinka MO (2020) Quantification of soil erosion and sediment yield for ungauged catchment using the RUSLE model: case study for Lake Basaka Catchment in Ethiopia. Lakes Reservoirs: Res Manage (March 2019):1-13. http://doi.wiley.com/. https://doi.org/10.1111//re.12312

Djoukbala O, Mazour M, Hasbaia M, Benselama O (2018) Estimating of water erosion in semiarid regions using RUSLE equation under GIS environment. Environ Earth Sci 77(9):345. https:// doi.org/10.1007/s12665-018-7532-1

Djoukbala O, Hasbaia M, Benselama O, Mazour M (2019) Comparison of the erosion prediction models from USLE, MUSLE and RUSLE in a Mediterranean watershed, case of Wadi Gazouana (NW of Algeria). Model Earth Syst Environ 5(2):725-743. http://link.springer.com/. https://doi.org/10.1007/s40808-018-0562-6

Gibson A, Hancock G (2019) Suspended sediment load estimation in an ungauged river in Southeastern Australia. River Res Appl (October): rra.3558. https://onlinelibrary.wiley.com/doi/abs/. https://doi.org/10.1002/rra.3558

Gitas IZ, Douros K, Minakou C, Silleos GN, Karydas CG (2009) Multi-temporal soil erosion risk assessment in N. Chalkidiki using a modified USLE raster model. EARSel eproceedings 8 (1):40-52

Hasbaia M et al (2012) Study of the water and sediment yields of Hodna Basin in the centre of Algeria, Examination of their impacts key words. In: ICSE6, Paris, pp 103-110

Hasbaia M et al (2018) Prediction of dams silting in semi-arid region using erosion map under GIS environment, case of Ksob watershed in Hodna region (Algeria), pp 781-783. http://link. springer.com/. https://doi.org/10.1007/978-3-319-70548-4_229

Hasbaia M, Hedjazi A, Benayada L (2012) Variabilite de 1'Érosion Hydrique Dans Le Bassin Du Hodna: Cas Du Sous-Bassin Versant de 1' Oued Elham. Revue Marocaine Des Sciences Agronomiques Et Vétérinaires 1(1):28-32

Hasbaia M, Paquier A, Herizi T (2017) Hydrological modeling of sediment transport in the semi-arid region, case of Soubella Watershed in Algeria. In: Water resources in arid areas: the way forward, pp 251-266. http://link.springer.com/. https://doi.org/10.1007/978-3-319-51856-5

Le Bissonnais Y, Dubreuil N, Daroussin J, Gorce M (2004) Modélisation et Cartographie de l'aléa d'érosion Des Sols à l'échelle Régionale. Étude Et Gestion Des Sols 11(3):307-321

Lu D, Li G, Valladares GS, Batistella M (2004) Mapping soil erosion risk in Rondonia, Brazilian Amazonia: using RUSLE. Remote Sens GIS Degrad Dev 15(5):499-512

Lu G et al (2012) Impacts of Danjiangkou Reservoir on sediment regime of the Hanjiang River. Hydrol Res 43(1-2):64-72

Medinger JM (1960) Transport solide des oueds algeriens. Annuaire Hydrologique de l'Algérie (Années 50-59), Alger

Selmi K, Khanchoul K (2016) Sediment load estimation in the Mellegue catchment, Algeria. J Water Land Dev 31(1):129-137

Toubal AK, Achite M, Ouillon S, Dehni A (2018) Soil erodibility mapping using the RUSLE model to prioritize erosion control in the Wadi Sahouat Basin, North-West of Algeria. Environ Monit Assess 190(4)

Walling DE, Fang D (2003) Recent trends in the suspended sediment loads of the World's Rivers. Global Planet Change 39(1-2):111-126

Zhang HY, Shi ZH, Fang NF, Guo MH (2015) Linking watershed geomorphic characteristics to sediment yield: evidence from the Loess Plateau of China. Geomorphology 234:19-27. https:// doi.org/10.1016/j.geomorph.2015.01.014 
Open Access This chapter is licensed under the terms of the Creative Commons Attribution 4.0 International License (http://creativecommons.org/licenses/by/4.0/), which permits use, sharing, adaptation, distribution and reproduction in any medium or format, as long as you give appropriate credit to the original author(s) and the source, provide a link to the Creative Commons license and indicate if changes were made.

The images or other third party material in this chapter are included in the chapter's Creative Commons license, unless indicated otherwise in a credit line to the material. If material is not included in the chapter's Creative Commons license and your intended use is not permitted by statutory regulation or exceeds the permitted use, you will need to obtain permission directly from the copyright holder.

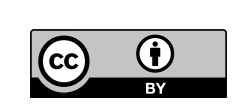

